\title{
Penerapan Tenun Tapestri Sebagai Elemen Dekoratif pada Produk Muslim Fashion
}

\author{
Putri Rahmah Sekarsari dan Citra Puspitasari \\ Program Studi Kriya, Fakultas Industri Kreatif, Universitas Telkom, Bandung, Indonesia \\ e-mail: putrhmh@gmail.com / citrapuspitasari@telkomuniveristy.ac.id
}

\begin{abstract}
Abstrak-Sejak tahun 2008, fenomena berhijrahnya para artis di Indonesia mulai marak terjadi. Fenomena ini membuat padangan masyarakat terhadap gaya hidup Islam, terutama dalam gaya berbusananya, menjadi lebih terbuka. Dengan adanya fenomena tersebut, membuat elemen dekorasi pada busana muslim menjadi semakin berkembang. Namun, berdasarkan hasil survei, observasi, dan studi literatur, didapati bahwa elemen dekorasi pada busana muslim masih terbatas menggunakan teknik permukaan seperti bordir, sablon, payet, dan sebagainya. Karena itu, hal ini dapat menjadi potensi untuk mengembangkan teknik struktur seperti tenun tapestri sebagai elemen dekorasi pada busana muslim. Metode yang digunakan yaitu metode kualitatif melalui studi literatur, observasi, wawancara, dan eksperimen. Setelah melalui eksperimen dan penelitian, penulis mendapati bahwa penggunaan teknik tenun tapestri pada busana muslim sangat berpotensi untuk dikembangkan dan dirasa lebih cocok untuk digunakan sebagai dekorasi untuk busana pesta.
\end{abstract}

Kata Kunci-fenomena artis hijrah, tenun, tapestri, busana muslim

\begin{abstract}
Since 2008, the phenomenon of entertainer who did 'hijrah' in Indonesia began to rife. This phenomenon makes the public view of the Islamic lifestyle, especially in its fashion style, more open. With this phenomenon, the decorative elements in Muslim fashion are growing. However, based on the results of surveys, observations, and literature studies, it is found that elements that are adjusted to Muslim clothing are still limited to the use of surface techniques such as embroidery, screen printing, sequins, and so on. Therefore this could be the potential to develop structural techniques such as woven rugs as an element of decoration in Muslim fashion. The method used is a qualitative method through the study of literature, observation, interviews, and experiments. After going through experiments and research, the author found that the use of tapestry weaving techniques in Muslim fashion was needed to be developed and felt more suitable for party clothing.
\end{abstract}

Keywords—phenomenon of hijrah artist, weave, tapestry, muslim fashion.

\section{PENDAHULUAN}

Perkembangan tren busana muslim di Indonesia mengalami peningkatan secara signifikan, yang mana disebabkan oleh beberapa hal seperti teknologi dan informasi yang berkembang, maraknya komunitas dakwah dan hijrah, serta mulai maraknya bazar dan pagelaran busana muslim di Indonesia [1].

Fenomena berhijrahnya para artis yang mulai marak terjadi pada tahun 2018 pun ikut turut andil dalam membuat busana muslim semakin terekspos. Selibriti/artis Muslimah dan Muslim Fashion Designer Indonesia berperan penting dalam peningkatan minat masyarakat untuk menggunakan busana muslim yang fashionable [2]. Selain itu, semakin Islaminya para generasi milenial muslim maka semakin berpotensi pula ekonomi pasar busana muslim. Berbagai bisnis startup dan perusahaan yang dikelola secara syarie sesuai kaidah Islam mulai bermunculan, beberapa diantaranya yaitu Ukhuwah Group oleh Teuku Wisnu dan Jannah Corp oleh Irwansyah [3]. Hijrah sudah menjadi tren yang dapat menjadi peluang bisnis bagi pelaku bisnis di dunia mode. Terbukti dari hasil salah satu wawancara pada seorang perwakilan dari Elzatta, yang merupakan salah satu perusahaan yang bergerak di industri busana muslim, fenomena berhijrahnya para artis di Indonesia yang mulai berhijab ini memberi efek positif dimana penjualan dalam pasar busana muslim mengalami peningkatan terutama pada tahun 2017 dan awal tahun 2018 [4].

Dengan meningkatnya peminat pada busana muslim, hal ini juga sejalan dengan berkembangnya rancangan dan elemen dekorasi pada busana muslim. Berhijrahnya para artis membuat dekorasi pada busana muslim menjadi berkembang karena diperlukannya busana yang sesuai dengan acara yang didatangi oleh para artis tersebut, misalnya untuk kebutuhan acara formal seperti acara penghargaan, tampil di atas panggung, dan sebagainya. Salah satu artis berhijrah yang fenomenal dan banyak disorot oleh media di Indonesia yaitu Dewi Sandra. Seperti dalam sebuah acara privat yang diselenggarakan, Dewi Sandra terlihat mengenakan gaun pesta dengan konsep Disney Princess karya desainer hijab Ayu Dyah Andari. gaun tersebut dihiasi elemen dekorasi dengan teknik permukaan berupa embellishments dan fabric manipulating. Karena itu rancangan elemen dekorasi pada busana muslim terus berkembang karena menyesuaikan kebutuhan pasar [5].

Pada busana muslim di Indonesia, penggunaan teknik struktur seperti tenun tapestri sebagai elemen dekorasi tidak terlalu umum dan kurang terekspos. Produk dari teknik tapestri umumnya digunakan sebagai home decor atau wall hanging [6]. Teknik tenun tapestri memiliki banyak variasi dalam pembuatannya sehingga berpotensi untuk dikembangkan hingga menjadi sebuah elemen dekorasi yang dapat diaplikasikan pada busana muslim.

\section{Tenun Tapestri}

Tapestri merupakan jenis struktur tenun sederhana (tabby) yang tersusun atas jalinan dari benang lungsin dan pakan [7]. Tenun tapestri berbeda dari tenunan lain karena karakteristik dari benang lungsinnya yang berbeda dari benang pakan. Benang lungsin pada tapestri tidak dapat terlihat langsung karena tertutup oleh benang pakan sepenuhnya dan umumnya tidak berwarna. Pembuatan 


\begin{tabular}{|c|c|c|c|}
\hline Eksperimen & Alat dan Bahan & Teknik & Keterangan \\
\hline Eksperimen Awal & $\begin{array}{l}\text { Benang kasur, benang } \\
\text { makrame, benang poly, } \\
\text { benang rayon, kain cerutti }\end{array}$ & $\begin{array}{l}\text { Teknik soumak, tusuk } \\
\text { diagonal, slit, dan tenun } \\
\text { pipih }\end{array}$ & $\begin{array}{l}\text { Bertujuan untuk mengeksplor } \\
\text { teknik dasar tenun tapestri dan } \\
\text { mencari tahu teknik dan bahan } \\
\text { yang paling sesuai untuk menjadi } \\
\text { sebuah elemen dekoratif }\end{array}$ \\
\hline Eksperimen Lanjutan & $\begin{array}{l}\text { Benang rayon, benang } \\
\text { poly, benang stick, kain } \\
\text { crepe, kain cerutti }\end{array}$ & $\begin{array}{l}\text { Teknik tenun pipih, } \\
\text { teknik slit tapestri, pleats, } \\
\text { teknik stem stitch }\end{array}$ & $\begin{array}{l}\text { Eksperimen dari pengembangan } \\
\text { eksperimen awal untuk } \\
\text { menghasilkan eksperimen berupa } \\
\text { lembaran dan modul. Dalam } \\
\text { eksperimen ini menggunakan } \\
\text { kombinasi antara kain tenun } \\
\text { tapestri dan kain yang di pleats } \\
\text { untuk menghasilkan lembaran } \\
\text { dengan teknik dan bahan yang } \\
\text { dirasa cocok berdasarkan hasil } \\
\text { eksperimen awal. }\end{array}$ \\
\hline Eksperimen Terpilih & $\begin{array}{l}\text { Benang rayon, benang } \\
\text { poly, benang stick, kain } \\
\text { crepe }\end{array}$ & $\begin{array}{l}\text { Teknik tenun pipih, } \\
\text { teknik slit tapestri, pleats, } \\
\text { teknik stem stitch }\end{array}$ & $\begin{array}{l}\text { Pengembangan eksperimen } \\
\text { berikut memiliki bentuk, volume, } \\
\text { dan berat yang cocok untuk } \\
\text { menjadi sebuah elemen dekorasi } \\
\text { pada busana sehingga terpilih } \\
\text { menjadi eksperimen akhir. }\end{array}$ \\
\hline
\end{tabular}
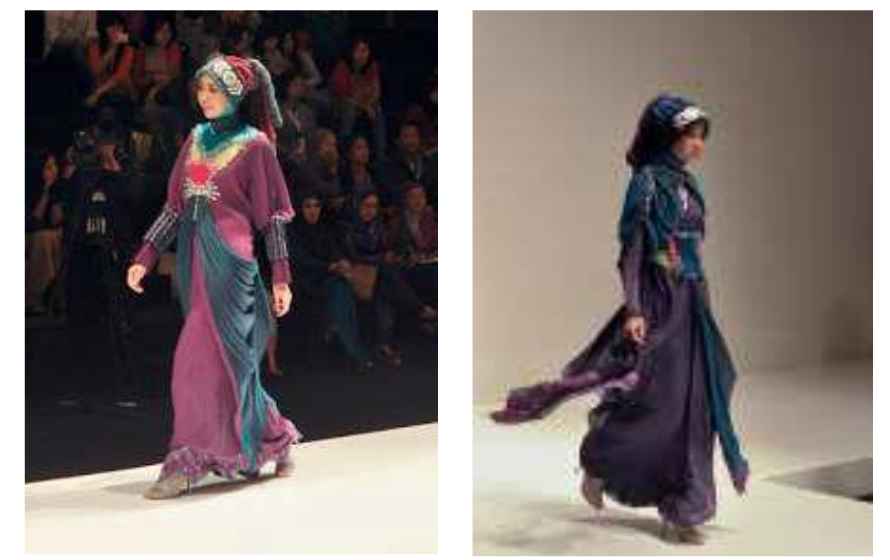

Gambar 1. Chromatic Reflection oleh Lilik Suharyati Sumber: thememorieskeeper.blogspot.com, diunduh 17 Desember 2019 , 11:30

rancangan busana muslimnya yang menggunakan teknik sulaman tapestri sebagai elemen dekoratif untuk menghasilkan tekstur dengan campuran permainan warna pada bahannya. Busana tersebut ditampilkan dalam pagelaran busana Indonesia Fashion Week dengan judul koleksi 'Chromatic Reflection' [6].

Gambar 1 merupakan gambar visual dari busana muslim rancangan desainer Lilik Suharyati yang bertajuk 'Chromatic Reflection'. Elemen dekoratif yang berwarnawarni pada bagian depan busana rancangan Lilik Suharyati menggunakan teknik sulaman tapestri dengan campuran warna pada bahan yang digunakan sehingga menciptakan tekstur warna-warni yang cukup menarik.

Tujuan utama penelitian ini dapat dijabarkan dalam tiga poin, yaitu seperti berikut:

1. Memanfaatkan peluang fenomena hijrah artis pada perancangan busana muslim.

2. Membuat eksperimen untuk elemen dekoratif yang cocok diaplikasikan pada busana muslim.

3. Menawarkan alternatif desain busana muslim dengan pengaplikasian elemen dekoratif menggunakan teknik tenun tapestri.

\section{METODE}

Metode penelitian dan pengumpulan data yang digunakan pada penelitian ini mengimplementasikan metode kualitatif yang terdiri dari:

\section{Studi Literatur}

Studi literatur dilakukan dengan cara mengumpulkan data 
meliputi busana muslim, fenomena hijrah artis di Indonesia, dan tenun tapestri melalui jurnal, buku, laporan skripsi, artikel, dan sumber lainnya. Hal ini bertujuan untuk memperkuat dasar dari penelitian dan mengetahui sejauh mana perkembangan dari topik yang diangkat.

\section{Observasi}

Observasi dilakukan dengan mengunjungi seminar yang berkaitan dengan topik penelitian, mengamati pasar busana muslim, dan mengamati tren busana muslim di Indonesia. Hal ini bertujuan untuk menganalisa hal apa saja yang berpotensi untuk dikembangkan dalam penelitian ini.

\section{Wawancara}

Wawancara dilakukan dengan salah satu desainer busana muslim di Indonesia yaitu Irna Mutiara. Wawancara ini dilakukan untuk mencari informasi meliputi perkembangan tren busana muslim di Indonesia, pengaruh artis dan fenomena artis berhijrah pada penjualan produk, serta potensi penggunaan teknik rekarakit sebagai elemen dekoratif.

\section{Eksperimen}

Eksperimen dilakukan dengan melalui tiga tahapan yaitu Eksperimen Awal, Eksperimen Lanjutan, dan kemudian Eksperimen Terpilih.

Tabel 1 menjelaskan tahapan eksperimen yang dilalui demi mencapai tujuan dari dilakukannya penelitian ini. Mulai dari eksperimen awal yang bertujuan untuk mengeksplor teknik yang digunakan, kemudian eksperimen lanjutan yang merupakan proses pengembangan dari eksperimen awal, hingga eksperimen terpilih yang merupakan pemilihan hasil eksperimen yang dirasa paling cocok untuk digunakan dalam penelitian ini.

\section{HASIL DAN PEMBAHASAN}
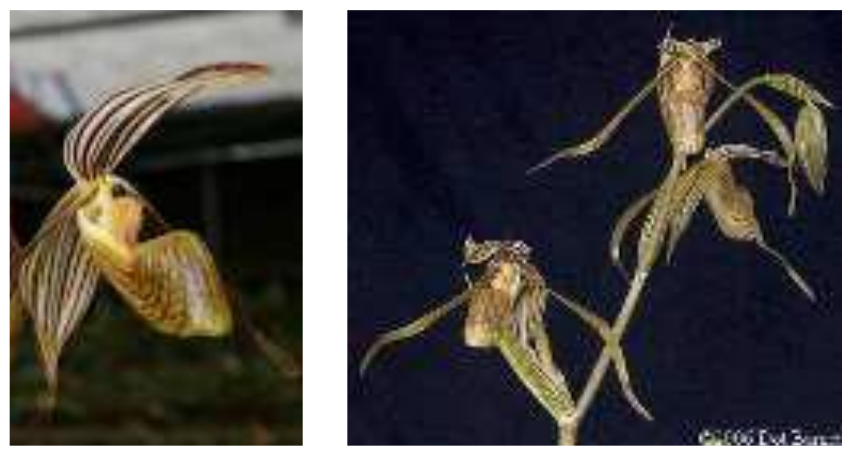

Gambar 2. Bunga Anggrek Kantung Kolopaking Sumber: alamendah.org, diunduh 09 Juli 2020, 00:39

Dalam membantu proses pengkaryaan penelitian, penulis melakukan tahapan sebagai berikut; menentukan muse berdasarkan fenomena hijrah artis, membuat image board sebagai acuan dalam melakukan eksperimen, membuat sketsa rancangan, kemudian melakukan proses penjahitan hingga menjadi sebuah produk utuh. Berdasarkan tahapan tersebut, peneliti menggunakan Dewi Sandra sebagai muse dalam penelitian ini karena Dewi Sandra merupakan salah satu artis Indonesia yang sudah berhijrah sejak tahun 2013 dan sosoknya sebagai artis yang berhijrah tidak asing dalam pandangan masyarakat [10].

Berdasarkan hasil observasi dan wawancara, didapatkan

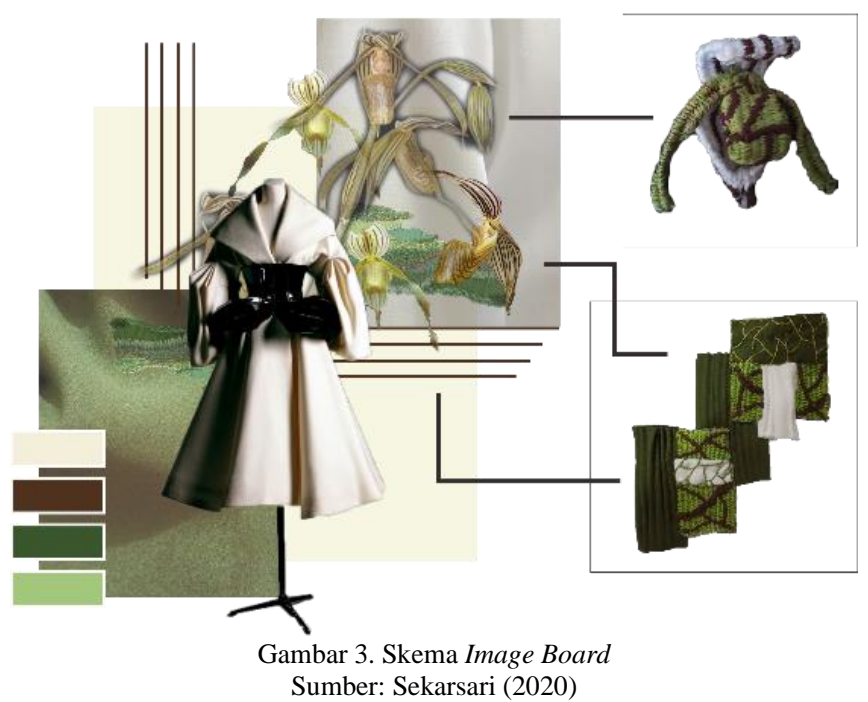

bahwa salah satu elemen dekoratif yang setiap tahunnya banyak digemari yaitu bunga, terutama dalam busana muslim. Karena itu, konsep dalam penelitian ini menggunakan salah satu bunga lokal Indonesia sebagai inspirasi. Bunga yang diangkat yaitu bunga Anggrek Kantung Kolopaking, pertimbangan dalam penggunaan bunga tersebut yaitu karena menyesuaikan dengan muse yang diangkat dalam penelitian ini yaitu Dewi Sandra yang memiliki image elegan. Bunga Anggrek tersebut memiliki bentuk visual yang elegan karena memiliki daun yang menjuntai di bagian sisi dan kelopaknya yang menyempit ke tengah sehingga menyerupai 'hour glass'.

Gambar 2 menunjukan gambaran visual Bunga Anggrek Kantung Kolopaking yang berasal dari Kalimantan Tengah. Seperti yang telah dijabarkan, bunga ini memiliki bentuk yang elegan sehingga cocok dengan konsep elegan dari muse yang diangkat.

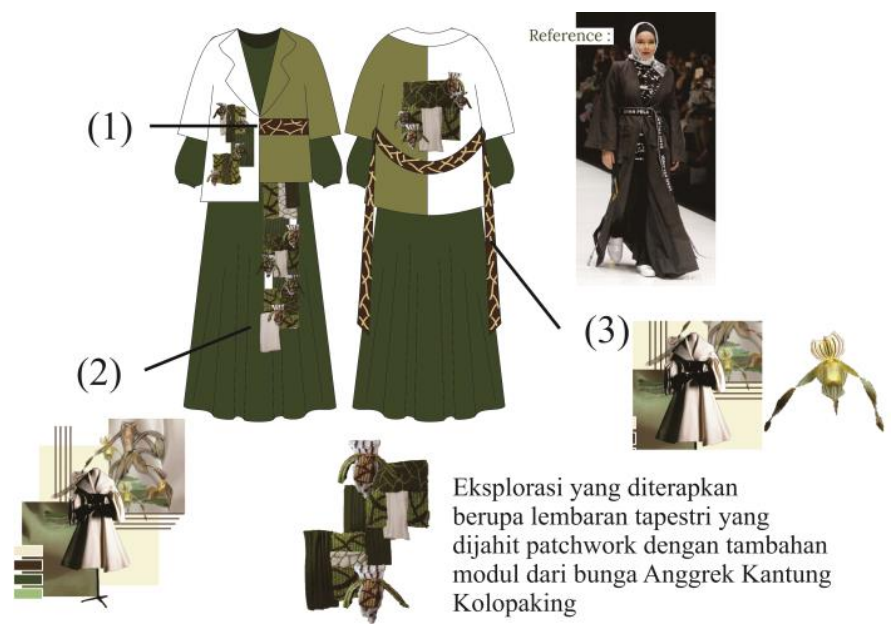

Gambar 4. Skema Sketsa Pengembangan Sumber: Sekarsari (2020)

\section{Konsep Desain}

Penelitian ini betujuan untuk membuat sebuah elemen dekoratif dengan teknik tenun tapestri yang cocok untuk diterapkan pada busana muslim. Konsep perancangan dalam penelitian ini yaitu konsep elegan dengan mengambil inspirasi dari bunga Anggrek Kantung Kolopaking.

Berdasarkan Gambar 3 yang merupakan skema dari image board tersebut, pada perancangan eksperimen modul, mengacu terhadap visual dari bunga Anggrek Kantung Kolopaking yang terdapat pada image board dengan 

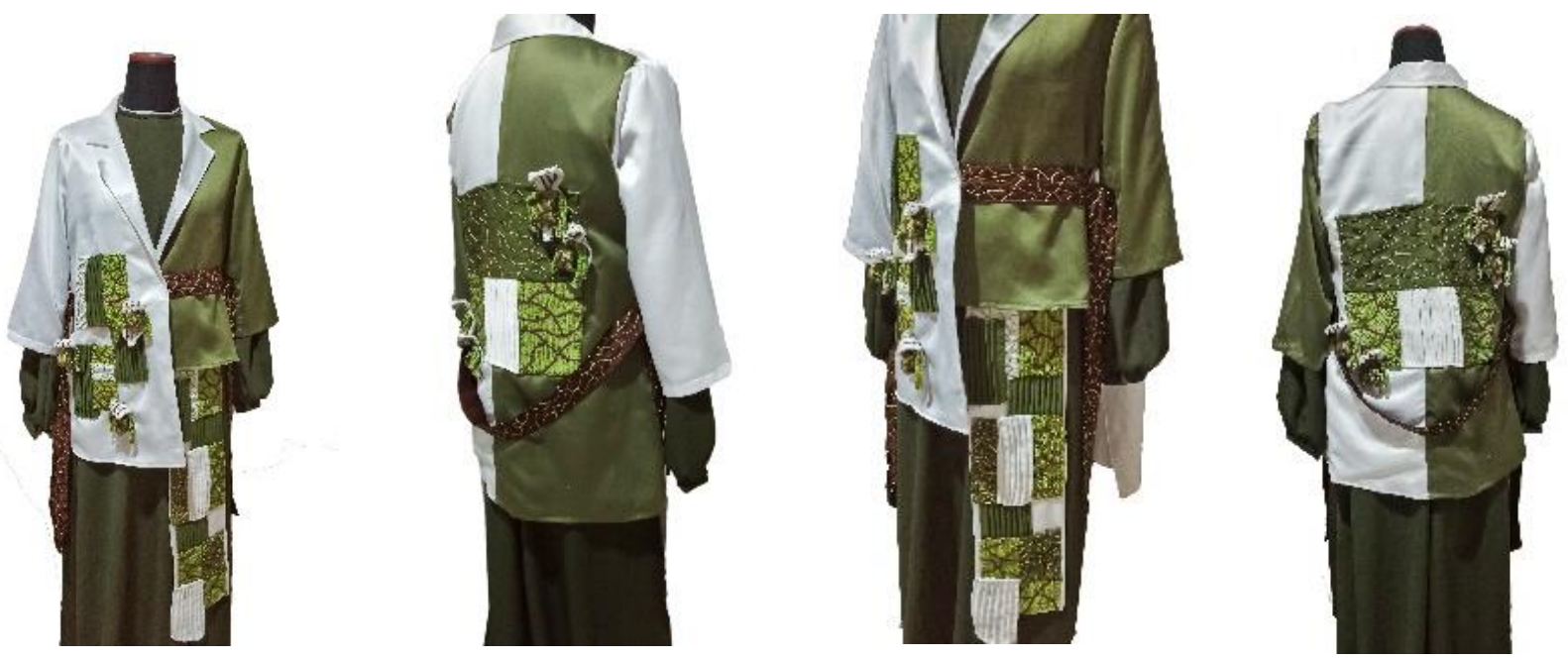

Gambar 5. Produk akhir

Sumber: Sekarsari (2020)

menggunakan teknik slit tapestri, teknik tenun pipih, dan stem stitch menggunakan benang poly, benang rayon, serta benang stick. Untuk eksperimen lembaran, menggunakan kombinasi antara kain yang di pleats dan disulam dengan kain tenun tapestri yang menggunakan teknik slit dan tenun pipih. Penyusunan lembaran tenun tapestri dirancang bertumpuk karena mengacu terhadap image board yang tersusun geometris dan bertumpuk. Warna yang digunakan yaitu warna coklat, hijau, dan putih karena mengacu terhadap objek inspirasi.

\section{Sketsa Perancangan}

Siluet dari rancangan busana ini mengacu terhadap objek inspirasi dan gaya busana Dewi Sandra yang merupakan muse dari penelitian ini. Secara umum, sketsa yang dibuat terdiri dari two piece yaitu outer dan dress dengan siluet Aline. Bahan yang digunakan yaitu satin dan woolpeach karena merujuk pada tema penelitian yang elegan [10]. Dalam pembuatan sketsa, terdapat tiga tahapan yang dilalui, yaitu; sketsa awal, sketsa terpilih, kemudian sketsa pengembangan. Tahapan tersebut dijabarkan sebagai berikut:

1. Sketsa Awal: Pada sketsa awal, dibuat beberapa busana rancangan yang terdiri dari outer dan dress A-line dengan potongan sederhana untuk menonjolkan elemen dekoratif pada busana rancangan. Penataan elemen dekoratif dan warna yang digunakan mengacu kepada image board.

2. Sketsa Terpilih: Setelah membuat beberapa sketsa awal, dipilih beberapa sketsa yang dirasa paling sesuai dengan konsep dan image board serta yang berpotensi untuk dikembangkan.

3. Sketsa Pengembangan: Sketsa pengembangan dibuat dari kombinasi beberapa sketsa awal dengan pertimbangan dari segi estetika, prinsip dan unsur desain, serta kesesuaian dengan image board. Perancangan sketsa pengembangan ini pun mengacu terhadap gaya berbusana muse dalam penelitian ini yaitu Dewi Sandra.

Sketsa pengembangan kemudian diproduksi menjadi produk akhir dari penelitian ini. Sketsa pengembangan dibuat dengan mempertimbangkan prinsip dan unsur desain agar menghasilkan sebuah produk yang harmonis secara visual. Dalam perancangannya, beberapa poin dari prinsip dan unsur desain yang diaplikasikan yaitu; irama, garis, warna, repetisi, dan perbandingan.

Berikut merupakan skema dari sketsa pengembangan berdasarkan kombinasi dari beberapa sketsa awal yang telah dibuat:

Penggayaan busana yang menggunakan outer merujuk pada gaya busana muse, Dewi Sandra, yang berdasarkan hasil observasi kerap menggunakan outer dalam kesehariannya.

Pada Gambar 4, terdapat beberapa poin utama dari perancangan dalam penelitian ini, poin-poin tersebut dapat dijabarkan sebagai berikut:

Poin 1:

Penggunaan ikat pinggang pada bagian depan merujuk kepada siluet busana yang terdapat di dalam moodboard dan bentuk visual dari bunga Anggrek Kantung Kolopaking.

Poin 2:

Pengaplikasian eksplorasi yang bertumpuk merujuk kepada penyusunan moodboard yang saling bertumpuk.

Poin 3:

Ikat pinggang yang menjuntai merupakan visualisasi dari bentuk daun bunga Anggrek Kantung Kolopaking yang menjuntai di bagian sisi bunga.

\section{Produk akhir}

Gambar 5 merupakan gambar visual dari hasil produksi berdasarkan sketsa pengembangan yang sebelumnya telah dilakukan. Produk ini terdiri dari outer yang berpotongan asimetris dengan belt yang didekorasi oleh lembaran tenun tapestri yang dipadukan dengan dress siluet A-line sederhana sehinga elemen dekorasi pada outer dan belt terlihat menonjol.

\section{KESIMPULAN}

Kesimpulan yang dapat ditarik berdasarkan penelitian yang telah dilakukan yaitu:

1. Fenomena berhijrahnya para artis di Indonesia membuka peluang lebih luas dalam merancang sebuah busana muslim karena fenomena tersebut dapat memengaruhi peningkatan penjualan produk busana muslim. 
2. Penggunaan teknik tenun tapestri berpotensi dan bisa digunakan untuk membuat sebuah elemen dekorasi yang cocok untuk diaplikasikan pada busana muslim. Dalam penelitian ini, teknik yang digunakan yaitu teknik tenun pipih dan slit tapestri. Kedua teknik tersebut digunakan karena dapat menghasilkan lembaran tenun yang cukup tipis dna ringan sehingga ketika diaplikasikan pada busana tidak akan mengerut karena beban berat.

3. Dengan menggunakan teknik tenun tapestri untuk membuat sebuah elemen dekoratif pada busana rancangan dapat memberi nilai lebih pada busana tersebut dari segi kriya dan dapat menonjolkan kreatifitas. Dalam perancangannya, busana yang dihasilkan dengan elemen dekorasi menggunakan teknik tenun tapestri dinilai lebih cocok sebagai busana pesta, karena penggunaan elemen dekorasi tersebut jika untuk pakaian sehari-hari dirasa kurang relevan.

4. Pemilihan kain untuk pengaplikasian dekorasi dengan teknik tenun tapestri perlu dipertimbangkan secara matang untuk menghindari ketidakseimbangan antara dekorasi dengan kain, karena hasil produk dari tenun tapestri umumnya cukup berat sehingga diperlukan kain yang cukup tebal dan kaku agar ketika diaplikasikan pada kain tidak akan mengerut.

5. Penggunaan benang disarankan tidak melebihi $1 \mathrm{~mm}$ dengan maksimal menggunakan 4 lapis benang karena jika

terlalu tebal akan menghasilkan lembaran yang bulky dan terlalu berat jika diaplikasikan pada busana.

6. Dalam perancangan busana muslim, penempatan elemen dekorasi pada busana rancangan perlu diperhatikan lebih lanjut untuk menghindari menarik perhatian pada bagian tertentu.
7. Sebagai rekomendasi, untuk perawatan produk yang menggunakan teknik struktur seperti tenun tapestri dianjurkan menggunakan dry clean untuk menghindari kerusakan pada produk.

\section{DAFTAR PUSTAKA}

[1] Dewi, Mayang Tresna, Citra Puspitasari (2018). "Penerapan Konsep Syar'i Modern Pada Desain Busana Pengantin Muslimah”. Jurnal ATRAT.

[2] Puspitasari, Citra and Dolah, Jasni (2018). "The Analysis of Integration between Hijab Concept and Fashion in Indonesia. In: The 3rd International Conference on Creative Media, Design and Technology (REKA 2018)". Universitas Negeri Sebelas Maret, Surakarta, Indonesia, pp. 325-328. ISBN: 978-94-6252-612-9.

[3] Yuswohady (2019). "Hijrah Movement". Diakses pada www.yuswohady.com. (04 Agustus 2020, 12:03).

[4] Budiartie dan Yuliastara. (2018). "Tren Hijrah, Agar Soleha atau Sekedar Gaya?". Diakses pada cnbcindonesia.com. (17 November 2019, 17:45).

[5] Yulistara, Arina. (2017). Foto: Ketika Dewi Sandra Dandan Ala Belle di 'Beauty\& the Beast'. Diakses pada www.wolipop.detik.com (27 Maret 2020, 14:33).

[6] Adystiani, Renny. Y. (2012). "Aplikasi Sulam Tapestry dalam Rancangan Busana Muslim”. Diakses pada www.archive.tabloidbintang.com. (10 Oktober 2019, 18:33).

[7] Drs. J. H. Hofenk de Graaff dan F. Boersma. (1997). "Tapestry Conversation". Amsterdam.

[8] Dwigantara, Agditya. (2011). "Kajian Karya Tapestri Binarul Anas Zaman Tahun 2006-2010”. Skripsi Sarjana pada FSSR UNS Surakarta.

[9] Kismayanti, Suci. (2017). "Permadani Perang Khas Afghanistan Pada Akhir Abad Ke-20". Skripsi Sarjana pada FAH UIN Syarif Hidayatullah Jakarta.

[10] Sekarsari, Putri Rahmah. (2020). "Perancangan Elemen Dekoratif Menggunakan Teknik Tenun Tapestri dengan Inspirasi Bunga Anggrek Kantung Kolopaking pada Busana Pesta Muslim”. Bandung: Universitas Telkom. 